\title{
Native Woody Plants Diversity and Density under Eucalyptus camaldulensis Plantation, in Gibie Valley, South Western Ethiopia
}

\author{
Shiferaw Alem*, Jindrich Pavlis \\ Faculty of Forestry and Wood Technology, Mendel University, Brno, Czech Republic \\ Email: "shife19@yahoo.com; jindra.pavlis@yahoo.com \\ Received July $30^{\text {th }}, 2012$; revised September $3^{\text {rd }}, 2012$; accepted September $18^{\text {th }}, 2012$
}

\begin{abstract}
The aim of the study was to assess the impact of E. camaldulensis plantation established in a semi-arid area on native woody plants diversity and density. Nested quadrant plot design, having an area of $15 \mathrm{~m} \times$ $15 \mathrm{~m}$ used to collect data. Totally, 37 species at the plantation and 30 species at the native woodland, belonging to 24 families, identified. Species diversity $\left(H^{\prime}\right)$ was 1.57 at the plantation and 2.09 at the woodland forest. As for density of understory woody plants (height $\geq 1 \mathrm{~m}$ ) the plantation forest harbored 6, 604 stems/ha while the native woodland had 7347 stems/ha. Seedling density (height $<1 \mathrm{~m}$ ) at the native woodland and at the plantation there were $11,436 \mathrm{stems} / \mathrm{ha}$ and $8865 \mathrm{stems} / \mathrm{ha}$, respectively. The similarity of woody species composition between the woodland forest and the plantation was low. However, in terms of autochthonous tree seed bank availability, authentic hypothesis seems to prove that if clear-cut patches replanted by introduced species that do not exceed 5 ha, they still significantly favour original forest regeneration and composition in a semi-arid area and surprisingly favors the regeneration of Dodonaea angustifolia and other native species important for soil conservation, timber, bee forage and medicinal use.
\end{abstract}

Keywords: Eucalyptus camaldulensis; Plantation; Diversity; Natural Regeneration; Semi-Arid; Woodland

\section{Introduction}

To relieve the shortage of wood caused by the extensive deforestation, eucalypts were introduced into Ethiopia in 18941895 from Australia (Pohjonen \& Pukkala, 1990). Nowadays eucalypts are amongst the most successful of the introduced plantation species, being quickly adopted by farmers, and widely distributed throughout developing tropical countries. The reason to be widespread is attributed to their fast growth, coppicing ability and less management requirements, the unpalatability of leaves, and their adaptability to a wide range of site conditions (Turnbull \& Pryor, 1978; FAO, 1981). Plantation forests can provide shelter, reduce edge effects, increase connectivity between forest fragments, and accommodate ecotone specialist and generalist forest species that might benefit from any forest type (Christian et al., 1998; Norton, 1998; Davis et al., 2001; Georgie et al., 2007; Richard et al., 2007; Felton et al., 2010).

Even though plantations do have such and many other uses, intensive monocultures of exotic plantations are widely viewed in a negative light mainly in relation to biological diversity conservation (Carnus et al., 2003). Though, it is not necessarily true in all cases as further proved by presented study. Among Eucalyptus, Pinus, and Tectona, which are the most commonly used species for plantation purpose throughout the world, Eucalyptus has attracted by far the most criticism (Evans, 1992; FAO, 2001), arguing that Eucalyptus spp.: 1) do not provide valuable organic matter but deplete soil nutrients; 2) pump up water resources used for agricultural crops; 3) suppress ground vegetation by secretion of allelopathic chemicals, and results in

${ }^{*}$ Corresponding author. unsuitable soil erosion control because of the less undergrowth vegetation (Jagger \& Pender, 2000).

On the other hand research on the tropical forest plantations indicated that they may occasionally promote the recruitment, establishment and succession of native woody species by functioning as foster ecosystems (Parrotta, 1997; Lugo et al., 1993). Some regeneration studies on plantations of Eucalyptus globulus, Eucalyptus saligna, Eucalyptus grandis, Pinus patula, Pinus radiata, Cupressus lusitanica and Grevillea robusta established at localities with high amounts of rain-fall and in relatively high altitudes of Ethiopia, also proved a surprising catalytic role of these monocultures with regard to habitat recolonization by native woody plants (Shiferaw \& Tadesse, 2009; Eshetu \& Olavi, 2003; Feyera et al., 2002; Feyera \& Demel, 2001; Eshetu, 2001; Bone et al., 1997; Colin \& Lauren, 1996; Isabele et al., 2008). However, studies on the regeneration of native woody plants under other plantation species suitable for dryer and low rainfall areas in lower altitudes are scarce.

The general aim of this study was to evaluate the potential role of exotic plantation species, in facilitating natural regeneration of woody plants in the semi-arid conditions of Ethiopia. With particular objective to assess naturally regenerated woody species diversity and density in E. camaldulensis plantation established at a degraded land in comparison with its neighboring autochthonous Terminalia-Combretum woodland.

\section{Materials and Methods}

\section{Site Description}

The study was conducted in the Abelti-Gibie forest priority 
area $\left(8^{\circ} 10^{\prime} \mathrm{N}, 37^{\circ} 34^{\prime} \mathrm{E}, 1493 \mathrm{~m}\right.$ above sea level) in Gibie valley of the Oromia state, southwestern part of Ethiopia (Figure 1). The physical feature of the study area is characterized by a rugged topography, and dominated by gentle slopes and a localized steep slopes ranging from $1 \%-27 \%$.

The climate character influencing the study area is derived from the closest climatologic station, (Jimma), which is situated $100 \mathrm{Km}$ southwest from the locality. The area prevails unimodal type of rainfall pattern, with the highest rain occurring between June and August. The mean annual temperature was $22.6^{\circ} \mathrm{C}$, with a mean minimum of $15^{\circ} \mathrm{C}$ to mean maximum of $30.34^{\circ} \mathrm{C}$. The hottest months occur from March to May (maximum $30.39^{\circ} \mathrm{C}$ ), while coldness occurs from September to November (minimum $20.13^{\circ} \mathrm{C}$ ).

\section{History of the Plantation}

The Eucalyptus plantation was established in the year 1983. Originally it was planted in a $2 \mathrm{~m} \times 2 \mathrm{~m}$ spacing although at the time of data collection its average tree density was 524 trees/ha. In the second and third year of its establishment the weeds under the plantation were removed through slashing. The plantation was established in 4 cell units, ranging from 5 to 10 ha, inside of the autochthonous woodland. The average tree diameter in the plantation was $15.58 \mathrm{~cm}$ and its mean height was $10.34 \mathrm{~m}$, having a basal area of $15.79 \mathrm{~m}^{2} / \mathrm{ha}$. The E. camaldulensis plantation is located about $3 \mathrm{~km}$ away from Abelti Village and highway asphalt road connecting Addis Ababa city to Jimma town dissects it in to different patches. The human and livestock pressure was minimum in the investigated plantation and neighboring woodland areas.

\section{Sampling Design and Data Collection}

\section{Sampling Design}

In total, 30 major sample plots, with an area of $225 \mathrm{~m}^{2}$ for each, were laid out along line transects. In each of the native woodland and the plantation forest 15 plots were sampled, independently. The distance between the consecutive plots along a line transect was $200 \mathrm{~m}$, and the spacing between two adjacent transect lines was also $200 \mathrm{~m}$. At each of the major square shaped plots $(15 \mathrm{~m} \times 15 \mathrm{~m})$, five subplots $(2 \mathrm{~m} \times 2 \mathrm{~m})$ were established to investigate natural seedling recruitment. Four of these subplots were designed and established at the corners of the major plots, and the last one in its center. A compass was used to align the transects.

\section{Vegetation Data Collection}

Woody species were determined and their diameter at breast height (DBH), of all trees at the sample plot, has been measured using a caliper and recorded in a data collection sheet. The height of the trees, were measured using hypsometer. Seedlings (height $<1 \mathrm{~m}$ ) data of woody species were collected in the five sub plots established within the major plot. Species identification in the field $(90 \%)$ has been based on expert knowledge, using tree identification field guide manuals (Azene, 2007; Fichtle \& Admasu, 1994). For specimens being difficult to identify in the field $(10 \%)$, voucher samples were collected, pressed and identified in the National Herbarium of Ethiopia, Addis Ababa University.

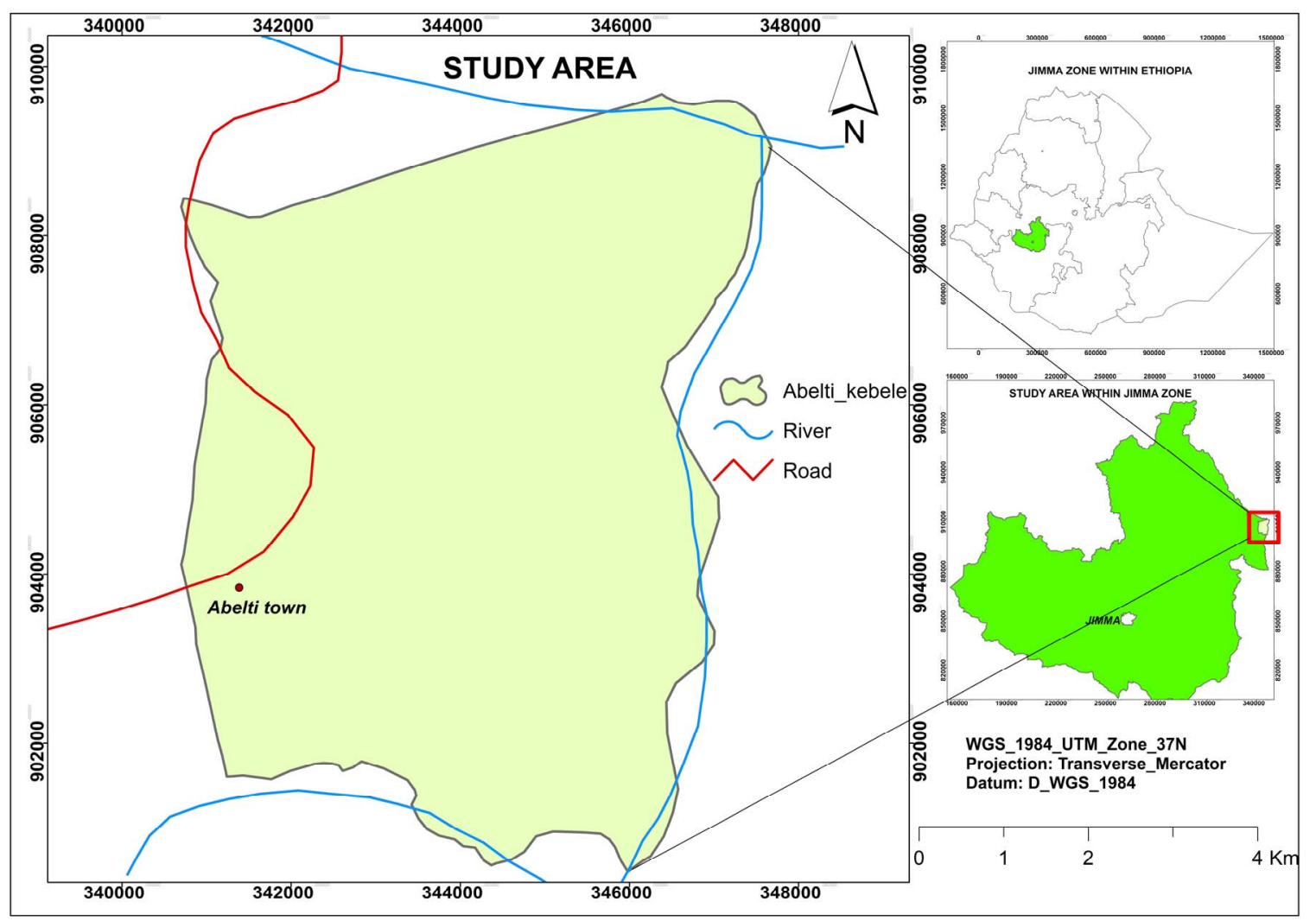

Figure 1.

Map of the study area. 


\section{Data Analyses}

Vegetation Structure and Diversity

The Shannon-Wiener Diversity Index $\left(H^{\prime}\right)$ was used to determine diversity of species in both the natural forest and plantation (1).

$$
H^{\prime}=-\sum_{i=1}^{S} p_{i} \ln p_{i}
$$

where $S$ is the number of species, $p_{i}$, the proportion of the individual species to the total, $n_{i} / N$.

The equitability (evenness) of species in E. camaldulensis plantation and the neighboring native woodland was calculated using $H^{\prime} / H^{\prime}{ }_{\max }$, where $H_{\text {max }}^{\prime}$ is $\ln$ (natural logarithm) of $S$ (number of species).

Moreover, a paired t-test was used to compare the species diversity $\left(H^{\prime}\right)$ of each plot in the native woodland and plantation forest (SAS, 2003). In this analysis, the diversity index $\left(H^{\prime}\right)$ for each major plot of the native woodland and the tree plantation was considered as a replication. Vegetation data collected from each major plot of the native woodland and plantation forest were used for structural analysis. The seedling data was also analyzed in a hectare base. Similarity index of understory regenerated native woody species in the plantation and native woodland was calculated using Jaccard's similarity coefficient (Krebs, 1989). In order to evaluate the distribution of a species in the native woodland and plantation forest, the Importance Value Index (IVI), which is a sum of relative values of density, frequency and dominance, was also calculated for each species (Kent \& Cooker, 1994).

In the IVI analysis only 41 tree species reached the DBH height or higher (Table 3), while the List of identified species, containing a total number of 43 species, includes also species under DBH threshold (Table 1).

Table 1.

List of the woody species found in E. camaldulensis plantation and the neighboring native woodland. $(\mathrm{B}=\mathrm{Birds}, \mathrm{M}=\mathrm{Mammals}$ and $\mathrm{W}=\mathrm{Wind})$.

\begin{tabular}{|c|c|c|c|c|c|c|}
\hline \multirow{2}{*}{ No } & \multirow{2}{*}{ Species } & \multicolumn{2}{|c|}{ Native woodland } & \multicolumn{2}{|c|}{ E. camaldulensis plantation } & \multirow{2}{*}{$\begin{array}{c}\text { Prevailing } \\
\text { dispersal agents }\end{array}$} \\
\hline & & Trees/ha & Seedlings/ha & Trees/ha & Seedlings/ha & \\
\hline 1 & Acacia abyssinica & & & 3 & & M \\
\hline 2 & Acacia nilotica & 9 & 33 & 18 & & M \\
\hline 3 & Acacia seyal & 15 & & & 600 & M \\
\hline 4 & Acacia senegal & 6 & & & & M \\
\hline 5 & Acacia tortilis & 24 & & 3 & & M \\
\hline 6 & Acokanthera schimperii & & & 3 & 133 & M \\
\hline 7 & Albizia gummifera & & & 3 & & M \\
\hline 8 & Calpurina aurea & & & 3 & & M, B \\
\hline 9 & Celtis africana & 3 & 36 & & & M, B \\
\hline 10 & Clausena anisata & 6 & & & & M \\
\hline 11 & Combretum ghasalense & 56 & 100 & 9 & 33 & $\mathrm{M}, \mathrm{W}$ \\
\hline 12 & Combretum molle & 35 & & & & $\mathrm{M}, \mathrm{W}$ \\
\hline 13 & Croton macrostachys & & & 9 & & M, B \\
\hline 14 & Deinbollia kilimandscharica & 141 & & 15 & 67 & M \\
\hline 15 & Dichrostachys cinerea & 626 & 1300 & 212 & 1967 & M \\
\hline 16 & Diospyros mespiliformis & 32 & 4567 & 3 & 33 & B \\
\hline 17 & Dodonea angustifolia & 2274 & & 4268 & 633 & M, B \\
\hline 18 & Dombeya schimperana & & & & 67 & M \\
\hline 19 & Dracaena afromontana & & & 6 & 67 & M, B \\
\hline 20 & Ekebergia capensis & & & 3 & & M, B \\
\hline 21 & Entada abyssinica & & & 12 & 33 & M \\
\hline 22 & Euclea schimperii & 921 & 500 & 729 & 733 & B \\
\hline 23 & Ficus sur & 29 & & 26 & & M, B \\
\hline 24 & Ficus vasta & 3 & & & & M, B \\
\hline 25 & Flacourtia indica & 29 & & 6 & & M, B \\
\hline 26 & Fleuggea virosa & 29 & 67 & 9 & & M, B \\
\hline 27 & Gardenia ternifolia & & 766 & & 133 & M \\
\hline 28 & Grewia bicolor & 126 & 300 & 38 & & M \\
\hline 29 & Grewia ferruginea & & & 97 & 333 & M, B \\
\hline 30 & Maytenus gracilipes & 118 & 433 & 24 & 267 & M, B \\
\hline 31 & Maytenus senegalensis & 212 & 300 & 24 & & M, B \\
\hline 32 & Millettia ferruginea & & & 12 & & $\mathrm{~B}$ \\
\hline 33 & Nuxia congesta & 3 & & 74 & 33 & $\mathrm{~B}, \mathrm{~W}$ \\
\hline 34 & Olea europaea & & & 50 & & M, B \\
\hline 35 & Oncoba spinosa & & & 3 & & M \\
\hline 36 & Piliostigma thonningii & 3 & & & & M \\
\hline 37 & Premna schimperii & 41 & & 41 & & M, B \\
\hline 38 & Rhus natalensis & 1465 & 700 & 447 & 1100 & M, B \\
\hline 39 & Schefflera abyssinica & 47 & & 3 & 33 & M, B \\
\hline 40 & Stereospermum kunthianum & 26 & & 6 & 33 & M \\
\hline 41 & Terminalia brownii & 1041 & 2267 & 421 & 2567 & M \\
\hline 42 & Ximenia americana & 21 & & 9 & & M \\
\hline 43 & Ziziphus spina-christii & 6 & 67 & 15 & & M, B \\
\hline
\end{tabular}




\section{Results and Discussion}

\section{Results}

\section{Floristic Composition and Diversity of Species}

In total, 43 species of trees and shrubs representing 24 families were determined in both $E$. camaldulensis plantation and the neighboring native woodland (Table 1). In total we recorded 30 species in the native woodland and 37 species in the plantation. Six species were recorded only within the native woodland, while thirteen species were recorded only within the eucalyptus plantation.

The diversity indexes $\left(H^{\prime}\right)$ of E. camaldulensis plantation and its neighboring native woodland were 1.568 and 2.091, respectively. The t-test statistics $\left(\mathrm{t}_{0.025}(28)=2.048, \mathrm{t}_{\mathrm{cal}}=5.97\right)$ results also revealed a significant difference in the diversity of species $\left(H^{\prime}\right)$ between each plot of the native woodland and the $E$. $c a$ maldulensis plantation $(P<0.02)$. The species distribution was 0.615 in the native woodland and 0.436 in the plantation.

\section{Vegetation Structure and Density of Species}

The relative density of trees and shrubs of $0.1-1 \mathrm{~cm}$ diameter was $18.3 \%$ in E. camaldulensis plantation and $12.7 \%$ in the neighboring native woodland (Table 2). The relative density of trees and shrubs $>12.1 \mathrm{~cm}$ diameter in native woodland and plantation were $0.1 \%$ and $0.5 \%$, respectively. The number of tree species in the higher diameter class for both of the $E$. $c a$ maldulensis and native woodland was less than that in the lower diameter class. The density of trees and shrubs (Height $>1 \mathrm{~m}$ ) was 7347 stems/ha in the neighboring native woodland and 6604 stems/ha in E. camaldulensis plantation, while the density of seedlings (height $<1 \mathrm{~m}$ ) was $11436 \mathrm{stems} / \mathrm{ha}$ in the neighboring native woodland and 8865 stems/ha in E. camaldulensis plantation. The density of trees of Terminalia brownii was higher in the native woodland (1041 stems/ha) as compared to

Table 2.

Relative density and number of species in each diameter class in $E$. camaldulensis plantation and neighboring native woodland.

\begin{tabular}{ccccc}
\hline $\begin{array}{c}\text { Diameter } \\
\text { class } \\
(\mathrm{cm})\end{array}$ & $\begin{array}{c}\text { E. camaldulensis plantation } \\
\text { density }(\%)\end{array}$ & $\begin{array}{c}\text { Neighboring native } \\
\text { woodland }\end{array}$ \\
\cline { 2 - 5 } species & $\begin{array}{c}\text { Relative } \\
\text { density }(\%)\end{array}$ & $\begin{array}{c}\text { Number of } \\
\text { species }\end{array}$ \\
\hline $0.1-1$ & 18.3 & 14 & 12.7 & 14 \\
$1.1-2$ & 26.5 & 19 & 27.3 & 20 \\
$2.1-3$ & 20.9 & 13 & 19.6 & 23 \\
$3.1-4$ & 13.7 & 16 & 17.3 & 22 \\
$4.1-5$ & 8.9 & 8 & 12.6 & 21 \\
$5.1-6$ & 5.3 & 12 & 6.4 & 17 \\
$6.1-7$ & 2.7 & 14 & 2.4 & 11 \\
$7.1-8$ & 1.5 & 12 & 0.8 & 8 \\
$8.1-9$ & 0.6 & 7 & 0.4 & 6 \\
$9.1-10$ & 0.6 & 8 & 0.1 & 6 \\
$10.1-11$ & 0.4 & 6 & 0.1 & 3 \\
$11.1-12$ & 0.1 & 2 & 0.1 & 6 \\
$\geq 12.1$ & 0.5 & 5 & & 3 \\
\hline
\end{tabular}

E. camaldulensis plantation (421 stems/ha). Whereas, seedling density was higher in the plantation forest $(2567 \mathrm{stems} / \mathrm{ha})$ in comparison with the native woodland (2267 stems/ha). Some species such as Gardenia ternifolia were recorded only at seedling level in both the plantation and native woodland (Table 1). The density of Dodonea angustifolia was much higher in the $E$. camaldulensis plantation (4268 stems/ha) than in the neighboring native woodland (2274 stems/ha). Dichrostachys cinerea had 1300 seedling stems per hectare in the native woodland and 1967 seedling stems per hectare in the plantation (Table 1). Generally, $47.4 \%$ of the species in the E. camaldulensis plantation and $47.7 \%$ of the species in the native woodland had less than 100 seedling stems per hectare. Similarly, 68.96\% and $85.29 \%$ of the identified species in the native woodland and plantation forest had less than 100 tree stems per hectare, respectively (Table 1).

\section{Importance Values of Species}

The Importance Value Index (IVI), ranges between 0.72 and 192.68 in the E. camaldulensis plantation and 6.71 and 144.92 at the neighboring native woodland (Table 3). Among the common species found in both forest types, importance values of A. nilotica, D. angustifolia, F. sur, N. congesta, and Z. spinachristii were higher in the $E$. camaldulensis plantation than in the native woodland (Table 3). Whereas, the IVIs of A. tortilis, C. ghasalense, D. kilimandscharica, D. cinerea, $F$. indica, $F$. virosa, M. gracilipes, M. senegalensis, $R$. natalensis and $T$. brownii were higher in neighboring native woodland than in $E$. camaldulensis plantation. D. angustifolia had a $100 \%$ relative frequency in E. camaldulensis plantation and $93.33 \%$ in the native woodland. Its relative density was $64.63 \%$ and $30.74 \%$ in the plantation and the native woodland, respectively. Generally, D. angustifolia had a higher IVI in the plantation (192.68) as compared to that of the native forest (144.92) (Table 3). The species, D. cinerea and T. brownii had $100 \%$ relative frequency in the native woodland. Of the common species identified in both forest types $77.27 \%$ of species had higher relative density in the native woodland than in the plantation forest. Similarly, $81.89 \%$ of the common species for both forest types had higher relative dominance value in the native woodland as compared with the plantation forest.

\section{Similarity of Understory Woody Species between the Native Woodland and the Plantation}

Similarity of woody species between plots is presented in Table 4. The minimum Jaccard's similarity index value is 0.095 , while the maximum similarity index was 0.78 . The highest similarity of species composition exists between plot 9 of the E. camaldulensis plantation and plot 1 of the neighboring native woodland. The lowest similarity in species composition was recorded between plot 1 of the $E$. camaldulensis plantation and plot 1 of the native woodland (Table 4). Most of the plots score a similarity index value of less than 0.50 .

\section{Discussion}

\section{Floristic Composition and Diversity of Species}

More number of species were identified in the E. camaldulensis plantation than in the neighboring native woodland. However, the result of the species diversity index indicated that the neighboring native woodland was more diverse than that of the E. camaldulensis plantation, and the species distribution in 
Table 3.

Relative density, relative frequency, relative dominance and Importance Value Index (IVI) of trees and shrubs (EC: Eucalyptus camaldulensis, NW: Native Woodland).

\begin{tabular}{|c|c|c|c|c|c|c|c|c|c|}
\hline \multirow[t]{2}{*}{ No } & \multirow[t]{2}{*}{ Species } & \multicolumn{2}{|c|}{ Relative frequency } & \multicolumn{2}{|c|}{ Relative density } & \multicolumn{2}{|c|}{ Relative dominance } & \multicolumn{2}{|l|}{ IVI } \\
\hline & & $\mathrm{EC}$ & NW & $\mathrm{EC}$ & NW & $\mathrm{EC}$ & NW & $\mathrm{EC}$ & NW \\
\hline 1 & A. abyssinica & 6.67 & & 0.04 & & 0.13 & & 6.84 & \\
\hline 2 & A. nilotica & 26.67 & 13.33 & 0.27 & 0.12 & 0.52 & 0.96 & 27.46 & 14.41 \\
\hline 3 & A. sayal & & 26.67 & & 0.20 & & 0.15 & & 27.02 \\
\hline 4 & A. senegal & & 13.33 & & 0.08 & & 0.10 & & 13.51 \\
\hline 5 & A. tortilis & 6.67 & 33.33 & 0.04 & 0.32 & 0.03 & 2.07 & 6.74 & 35.72 \\
\hline 6 & A. schimperii & 6.67 & & 0.04 & & 0.03 & & 6.74 & \\
\hline 7 & A. gummifera & 6.67 & & 0.04 & & 0.26 & & 6.97 & \\
\hline 8 & C. aurea & 6.67 & & 0.04 & & & & 6.71 & \\
\hline 9 & C. africana & & 6.67 & & 0.04 & & 0.04 & & 6.75 \\
\hline 10 & C. anisata & & 6.67 & & 0.04 & & 0.01 & & 6.72 \\
\hline 11 & C. ghasalense & 6.67 & 46.67 & 0.13 & 0.75 & 0.13 & 1.66 & 6.93 & 49.08 \\
\hline 12 & C. molle & & 6.67 & & 0.47 & & 0.94 & & 8.08 \\
\hline 13 & C. macrostachys & 13.33 & & 0.13 & & 1.66 & & 15.12 & \\
\hline 14 & D. kilimandscharica & 20.00 & 60.00 & 0.22 & 1.90 & 0.20 & 2.79 & 20.42 & 64.69 \\
\hline 15 & D. cinerea & 66.67 & 100.00 & 3.25 & 9.13 & 3.82 & 4.13 & 73.74 & 113.26 \\
\hline 16 & D. mespiliformis & 6.67 & 26.67 & 0.04 & 0.43 & 0.10 & 1.16 & 6.81 & 28.26 \\
\hline 17 & D. angustifolia & 100.00 & 93.33 & 64.63 & 30.74 & 28.05 & 20.85 & 192.68 & 144.92 \\
\hline 18 & D. afromontana & 13.33 & & 0.09 & & 0.02 & & 13.44 & \\
\hline 19 & E. capensis & 6.67 & & 0.04 & & 0.01 & & 6.72 & \\
\hline 20 & E. abyssinica & 6.67 & & 0.18 & & 0.69 & & 7.54 & \\
\hline 21 & E. schimperii & 86.67 & 86.67 & 11.05 & 12.37 & 10.42 & 10.49 & 108.14 & 109.53 \\
\hline 22 & F. sur & 33.33 & 6.67 & 0.40 & 0.40 & 27.45 & 1.10 & 61.18 & 8.17 \\
\hline 23 & F. vasta & & 6.67 & & 0.04 & & 0.70 & & 7.41 \\
\hline 24 & F. indica & 13.33 & 26.67 & 0.09 & 0.40 & 0.01 & 0.27 & 13.43 & 27.34 \\
\hline 25 & F. virosa & 6.67 & 53.33 & 0.13 & 0.40 & 0.01 & 0.18 & 6.81 & 53.91 \\
\hline 26 & G. bicolor & 46.67 & 66.67 & 0.58 & 1.70 & 0.70 & 2.36 & 47.95 & 70.73 \\
\hline 27 & G. ferruginea & 46.67 & & 1.47 & & 1.28 & & 49.42 & \\
\hline 28 & M. gracilipes & 26.67 & 66.67 & 0.36 & 1.54 & 0.62 & 1.48 & 27.65 & 69.69 \\
\hline 29 & M. senegalensis & 26.67 & 60.00 & 0.36 & 2.84 & 0.36 & 3.73 & 27.39 & 66.57 \\
\hline 30 & M. ferruginea & 20.00 & & 0.18 & & 0.23 & & 20.41 & \\
\hline 31 & $N$. congesta & 33.33 & 6.67 & 1.11 & 0.04 & 0.79 & 0.09 & 35.23 & 6.80 \\
\hline 32 & O. africana & 40.00 & & 0.78 & & 0.42 & & 41.20 & \\
\hline 33 & O. spinosa & 6.67 & & 0.04 & & 0.02 & & 6.73 & \\
\hline 34 & P. thonningii & & 13.33 & & 0.43 & & 1.53 & & 15.29 \\
\hline 35 & P. schimperii & 26.67 & 26.67 & 0.62 & 0.55 & 0.09 & 0.42 & 27.38 & 27.64 \\
\hline 36 & R. natalensis & 100.00 & 100.00 & 6.77 & 19.68 & 11.34 & 16.81 & 118.11 & 136.49 \\
\hline 37 & S. abyssinica & 6.67 & 40.00 & 0.04 & 0.63 & 0.01 & 0.59 & 6.72 & 41.22 \\
\hline 38 & S. kunthianuum & 13.33 & 20.00 & 0.09 & 0.36 & 0.23 & 0.19 & 13.65 & 20.55 \\
\hline 39 & T. brownii & 73.33 & 100.00 & 6.37 & 14.03 & 9.17 & 24.66 & 88.87 & 138.69 \\
\hline 40 & X. americana & 20.00 & 20.00 & 0.13 & 0.28 & 0.25 & 0.03 & 20.38 & 20.31 \\
\hline 41 & Z. spina-christii & 20.00 & 6.67 & 0.22 & 0.08 & 0.91 & 0.10 & 21.13 & 6.85 \\
\hline
\end{tabular}


Table 4.

Jaccard's Coefficient of similarity in species composition of naturally regenerated woody plants between sample plots of E. camaldulensis plantation (EC) and the neighboring native woodland (NW).

\begin{tabular}{|c|c|c|c|c|c|c|c|c|c|c|c|c|c|c|c|}
\hline $\begin{array}{c}\text { Forest } \\
\text { type }\end{array}$ & $\mathrm{EC} 1$ & $\mathrm{EC} 2$ & $\mathrm{EC} 3$ & $\mathrm{EC} 4$ & EC5 & EC6 & EC7 & EC8 & EC9 & EC10 & EC11 & $\mathrm{EC} 12$ & $\mathrm{EC} 13$ & EC14 & EC15 \\
\hline NW1 & 0.095 & 0.26 & 0.15 & 0.38 & 0.38 & 0.44 & 0.30 & 0.30 & 0.78 & 0.25 & 0.28 & 0.35 & 0.24 & 0.24 & 0.24 \\
\hline NW2 & $*$ & 0.36 & 0.3 & 0.55 & 0.37 & 0.26 & 0.25 & 0.33 & 0.35 & 0.5 & 0.55 & 0.4 & 0.31 & 0.45 & 0.45 \\
\hline NW3 & $*$ & $*$ & 0.3 & 0.42 & 0.23 & 0.26 & 0.18 & 0.33 & 0.21 & 0.25 & 0.41 & 0.31 & 0.25 & 0.33 & 0.45 \\
\hline NW4 & $*$ & $*$ & $*$ & 0.31 & 0.36 & 0.43 & 0.33 & 0.33 & 0.35 & 0.27 & 0.4 & 0.39 & 0.25 & 0.25 & 0.33 \\
\hline NW5 & * & $*$ & * & $*$ & 0.43 & 0.33 & 0.35 & 0.29 & 0.43 & 0.29 & 0.33 & 0.47 & 0.33 & 0.28 & 0.28 \\
\hline NW6 & $*$ & * & * & $*$ & * & 0.36 & 0.32 & 0.32 & 0.4 & 0.33 & 0.33 & 0.37 & 0.24 & 0.31 & 0.31 \\
\hline NW7 & $*$ & $*$ & * & $*$ & * & $*$ & 0.28 & 0.44 & 0.44 & 0.38 & 0.33 & 0.41 & 0.26 & 0.36 & 0.36 \\
\hline NW8 & $*$ & $*$ & * & * & * & $*$ & * & 0.25 & 0.27 & 0.33 & 0.29 & 0.37 & 0.24 & 0.24 & 0.31 \\
\hline NW9 & $*$ & $*$ & * & $*$ & * & $*$ & * & $*$ & 0.35 & 0.36 & 0.42 & 0.5 & 0.31 & 0.33 & 0.45 \\
\hline NW10 & * & $*$ & * & * & * & * & * & * & & 0.29 & 0.33 & 0.33 & 0.26 & 0.36 & 0.36 \\
\hline NW11 & $*$ & $*$ & * & $*$ & * & * & $*$ & * & $*$ & * & 0.27 & 0.21 & 0.15 & 0.2 & 0.2 \\
\hline NW12 & $*$ & $*$ & * & $*$ & $*$ & $*$ & * & $*$ & $*$ & $*$ & $*$ & 0.29 & 0.22 & 0.31 & 0.31 \\
\hline NW13 & $*$ & $*$ & * & $*$ & * & $*$ & * & * & $*$ & $*$ & $*$ & * & 0.31 & 0.33 & 0.45 \\
\hline NW14 & $*$ & $*$ & * & * & * & $*$ & $*$ & * & $*$ & $*$ & $*$ & $*$ & $*$ & 0.33 & 0.33 \\
\hline NW15 & $*$ & $*$ & $*$ & $*$ & * & $*$ & * & $*$ & $*$ & $*$ & $*$ & $*$ & $*$ & $*$ & 0.5 \\
\hline
\end{tabular}

the neighboring native woodland $(0.615)$ was more even than that of the E. camaldulensis plantation (0.436). Even if an absolute number of species was higher in the E. camaldulensis plantation, the native woodland has a higher diversity value which is contributed by the higher distribution of species throughout the plots. However, in the present study, the number of species recorded in the E. camaldulensis plantation was higher than that recorded in other exotic plantation species in Ethiopia. Feyera and Demel (2001) recorded a total of 18 and 11 naturally regenerated woody species under 14 years and 24 years $C$. lusitanica plantation within the area of the central Ethiopian highlands. They also recorded 17, 15, 26 and 27 native woody species under 24 year $P$. patula, 15 year $P$. radiata, 26 year Juniperus procera and 17 year E. globulus plantations. In a similar study of uneven aged plantations established in the dry afro-mountain areas of Ethiopia, Feyera et al. (2002) recorded under $C$. lusitanica plantations 30 woody species in a 9 year old stand, 22 species in a 17 year old stand and 17 species in a 25 year old plantation. The same author recorded for $E$. globulus plantations: 16 species in a 13 year old stand, 13 species in a 16 year old stand and 17 species in a 22 year old plantation. This study also found a total of 18,23 and 25 native woody species in 11, 22 and 27 years of E. saligna plantation, respectively and 18, 17 and 27 woody species in a 10,21 and 28 years of $P$. patula plantation (Feyera et al., 2002).

Similarly, Eshetu and Olavi (2003) recorded a total of 22 native woody species in an 11 year E. globulus plantation in Menagesha, where there was remnant natural forest, and 20 native woody species in a 37 year old E. globulus plantation in Chancho, where natural forests were absent. Likely, the number of identified species in this study is also higher than the study result of Eshetu (2001), under the plantations of P. patula, $C$. lusitanica, J. procera, and Grevillea robusta. These differences might be associated with the species pool available in the sur- rounding natural forest, local climatic conditions, soil seed bank, and effects of the plantations on the different tree species and its density. Seed dispersal agents may also play a great role in dispersing the seeds from the surrounding native woodlands species pool to the E. camaldulensis plantation, in which mammals, birds and wind were the major agents of dispersal for the identified species in the study area (Table 1).

\section{Vegetation Structure and Density of Species}

The DBH structure of species can reveal the population dynamics. Therefore, based on diameter class distribution and density, the effects of plantation and natural forests on the recruitment of different species can be inferred. With increase in diameter class, the number of species decreased both in native woodland and E. camaldulensis plantation considerably (Table 2). Therefore, in both of the native woodland and the $E$. $c a$ maldulensis plantation, the tree species in lower diameter classes are dominant. Trees in the higher diameter classes are few in the E. camaldulensis plantation, which might be due to the age of the plantation, or the growth nature of identified species. Although receiving low amounts of rainfall, relative density of trees/shrubs identified in the E. camaldulensis plantation was higher as compared with other findings from other plantations of C. lustanica, E. globulus, E. saligna, G. robusta, $J$. procera, P. patula, P. radiata, in the central and southern Ethiopia (Eshetu, 2001; Feyera et al., 2002; Feyera \& Demel, 2001). This difference might be associated with the low relative density of $E$. camaldulensis plantation (524 trees/ha) in the present study site as compared with the other studies, in which low density of overstory trees allowed more light and more open spaces to the undergrowth woody plants. Georgie et al. (2007) stated that light levels are positively associated with vascular plant species richness and permanent open spaces in plantation forests provide an opportunity for enhancing biodi- 
versity in the plantations. The undergrowth woody plants might be also favored by the plantation age and rotation in which there was no thinning and continuous harvesting of the plantation. Mitschka (2002), indicated that earlier thinning or longer rotations strongly affects biodiversity.

Some species, such as $T$. brownii, $R$. natalensis, and $E$. schimperii, have a relatively higher number of seedling densities in E. camaldulensis plantation, compared to those in the native woodland (Table 3 ). This result may indicate that these species are not threatened at all by any allelopathic compounds from $E$. camaldulensis plantation as it is often the case of $E u$ calyptus and/or can tolerate shade. It may even indicate that, as an over story tree, the E. camaldulensis plantation fosters the natural regeneration of these species. Scientific evidences indicated that, some eucalypt plantations have the potential in enhancing the recruitment, establishment, and successions of certain native woody species (Loumeto \& Huttlee, 1997; Eshetu, 2001; Feyera et al., 2002; Mulugeta \& Demel, 2004). On the other hand, some species which are well distributed throughout in their diameter classes in the native woodland were not recorded in the E. camaldulensis plantation. This may show that E. camaldulensis plantation may have a negative effect on the undergrowth of some species, while it favors the others, which can be related to light demanding nature of the species as for regeneration and growth, allelopathic effect, microclimate, competition etc. The E. camaldulensis plantation was found favoring $D$. angustifolia, much better than the native woodland, which can be used for soil conservation. This can indicate that $D$. angustifolia is one potential species to regenerate under $E$. camaldulensis plantation in semiarid areas, increase the ground cover, and can help to reduce soil erosion and can increase biodiversity in the plantation.

\section{Importance Values of Species}

The IVI is considered to show greater ecological significance in plant distribution than in absolute density (Fosberg, 1961). D. angustifolia found in E. camaldulensis plantation has higher IVI and basal area than that in the native woodland. This indicates that the plantation favors the distribution of this plant species in its understory. Also, the IVI result indicated that the $E$. camaldulensis plantation perhaps facilitated and fostered the distribution of A. nilotica, F. sur, N. congesta, and Z. spinachristii. While, A. tortilis, C. ghasalense, D. kilimandscharica, $D$. cinerea, F. indica, F. virosa, M. gracilipes, M. senegalensis, $R$. natalensis and $T$. brownii were better distributed in the neighboring native woodland than in E. camaldulensis plantation.

\section{Similarity of Understory Woody Species between the Native Woodland and the Plantation}

The present study indicated the least similarity of woody species composition between the native woodland forest and $E$. camaldulensis plantation. This might be due to the climatic conditions of the area, the available species pool in the surrounding native woodland forest, and impact of the plantation in its underneath woody vegetation. The findings of this study resonate with former studies conducted in Ethiopia (Feyera et al., 2002; Eshetu, 2001; Feyera \& Demel, 2001), which reported low similarity among different plantations and neighboring natural forests. The age of the plantation, the light intensity reaching the forest floor and the amount of annual rainfall may influence understory plant distribution.

\section{Conclusion}

All the results indicated, the plantation being established in a degraded and semiarid area, harbored significant number of indigenous woody species in its underneath canopy. Many of these autochthonous trees are important for their timber production capacity, bees forage, medicinal or soil conservation potential, being also found at neighboring native woodland or under other plantations of higher rainfall regime areas. Authentic data seems to prove that smaller clear-cut patches, replanted by introduced species, still significantly favor original forest regeneration and composition. Thus, E. camaldulensis plantation forest, when it is established with wider spacing, can allow more light to reach to the understory, and serve as a nurse tree, intern plays a role in biodiversity conservation in a semiarid area and to rehabilitate degraded lands.

\section{Acknowledgements}

This study was financed by Forestry Research Center, Ethiopian Institute of Agricultural Research (EIAR), and Interni Grantova Agentura (IGA) of Mendel University in Brno (with a project code of 52/2010). The authors would like to acknowledge Genene Tesfaye, Yiheyis Tadesse and Solomon Bacha for their support in data collection. Thanks also to Ashenafi Burka, for his support in preparing map of the study area.

\section{REFERENCES}

Azene, B.T., Beánie, A., \& Tengnas, B. (2007). Useful trees and shrubs for Ethiopia: Identification, propagation and management for 17 agro-climatic zones. Nairobi: Regional Land Management Unit.

Bone, R., Lawrence, M., \& Magombo, Z. (1997). The effect of Eucalyptus camaldulensis (Dehn) plantation on native woodland recovery on Ulumba mountain, southern Malawi. Forest Ecology and Management, 99, 83-99. doi:10.1016/S0378-1127(97)00196-5

Carnus, J. M., Parrotta, J., Brockerhoff, E. G., Arbes, M., Jactel, H., Kremer, A., Lamb, D., Hara, K. O., \& Walter, B. (2003). Planted forests and biodiversity. UNFF Inter-Sessional Experts Meeting on the Role of Planted Forests in Sustainable Forest Management, Wellington, 25-27 March 2003, 54.

Christian, D. P., Hoffman, W., Hanowski, J. M., Niemi, G. J., \& Beyea, J. (1998). Bird and mammal diversity on woody biomass plantations in North America. Biomass and Bioenergy, 14, 395-402. doi:10.1016/S0961-9534(97)10076-9

Colin, A. C., \& Lauren, J. C. (1996). Exotic tree plantations and the regeneration of natural forests in Kibale national park, Uganda. Biological Conservation, 76, 253-257. doi:10.1016/0006-3207(95)00124-7

Davis, A. J., Huijbregts, H., \& Krikken, J. (2001). The role of local and regional processes in shaping dung beetle communities in tropical forest plantations in Borneo. Global Ecology and Biogeography, 9, 281-292. doi:10.1046/j.1365-2699.2000.00189.x

Eshetu, Y., \& Olavi, L. (2003). Indigenous woody species diversity in Eucalyptus globulus Labill. ssp. globulus plantations in the Ethiopian highlands. Biodiversity and Conservation, 12, 567-582. doi:10.1023/A:1022483700992

Eshetu, Y. (2001). Diversity of naturally regenerated native woody species in forest plantations in the Ethiopian highlands. New Forests, 22, 159-177. doi:10.1023/A:1015629327039

Evans, J. (1992). Plantation forestry in the tropics (2nd ed.). New York: Oxford University Press.

FAO (1981). Eucalypts for planting: FAO forestry and forest products studies 11. Rome: FAO. 
FAO (2001). State of the world's forests. Rome: FAO.

Felton, A., Knight, E., Wood, J., Zammit, C., \& Lindenmayer, D. (2010). A meta-analysis of fauna and flora species richness and abundance in plantations and pasture lands. Biological Conservation, 143, 545-554. doi:10.1016/j.biocon.2009.11.030

Feyera, S., \& Demel, T. (2001). Regeneration of indigenous woody species under the canopy of tree plantations in central Ethiopia. Tropical Ecology, 42, 175-185.

Feyera, S., Demel, T., \& Bertake, N. (2002). Native woody species regeneration in exotic tree plantations at Munessa-Shashemene forest, Southern Ethiopia. New Forests, 24, 131-145. doi:10.1023/A:1021201107373

Fichtl, R., \& Admasu, A. (1994). Honeybee flora of ethiopia. Mannheim: Benedict press.

Fosberg, F. R. (1961). A classification of vegetation for general purposes. Tropical Ecology, 2, 1-28.

Georgie, F. S., Susan, I., Daniel, L. K., Saoirse, O., \& Fraser, J. G. (2007). Enhancing vegetation diversity in glades, rides and roads in plantation forests. Biological Conservation, 136, 283-294. doi:10.1016/j.biocon.2006.12.001

Isabele, A., Christian, M., \& Andre, B. (2008). Can plantations develop understory biological and physical attributes of naturally regenerated forests? Biological Conservation, 141, 2461-2476. doi:10.1016/j.biocon.2008.07.007

Jagger, P., \& Pender, J. (2000). The role of trees for sustainable management of less favored lands: The case of eucalypts in Ethiopia. Washington: International Food Research Institute.

Kent, M., \& Coker, P. (1994). Vegetation description and analysis: A practical approach. Hoboken: John Wiley and Sons.

Krebs, C. J. (1989). Ecological methodology. New York: Harper and Row Cop.

Loumeto, J., \& Huttel, C. (1997). Understory vegetation in fast growing tree plantations on savanna soils in Congo. Forest Ecology and Management, 99, 65-81. doi:10.1016/S0378-1127(97)00195-3

Lugo, A. E. (1992). Tree plantation for rehabilitating damaged lands in the tropics. In: M. K. Wali (Ed.), Environmental rehabilitation (pp. 247-255). Hague: SPB Academic Publishing.

Mitschka, J. H. (2002). Rationale and methods for conserving biodiversity in plantation forests. Forest Ecology and Management, 155, 8195. doi:10.1016/S0378-1127(01)00549-7

Mulugeta, L., \& Demel, T. (2004). Restoration of native forest flora in the degraded high lands of Ethiopia: Constraints and opportunities. Ethiopian Journal of Science, 27, 75-90.

Norton, D. A. (1998). Indigenous biodiversity conservation and plantation forestry: Options for the future. New Zealand Forest, 43, 34-39.

Parrotta, J. A., Turnbull, W. J., \& Jones, N. (1997). Catalysing native forest regeneration on degraded tropical lands. Forest Ecology and Management, 99, 1-7. doi:10.1016/S0378-1127(97)00190-4

Pohjonen, V., \& Pukkala, T. (1990). Eucalyptus globulus in Ethiopian forestry. Forest Ecology and Management, 36, 19-31. doi:10.1016/0378-1127(90)90061-F

Richard, H. L., Edward, G. M, Phoebe, M., \& Philippa, N. (2007). Eucalypt plantations as habitat for birds on previously cleared farmland in south-eastern Australia. Biological Conservation, 137, 533548. doi:10.1016/j.biocon.2007.03.012

SAS (2003). SAS system software. Version 9.1. Cary, NC: SAS Institute Inc.

Shiferaw, A., \& Tadesse, W. (2009). A comparative assessment on regeneration status of indigenous woody plants in Eucalyptus grandis plantation and adjacent natural forest. Journal of Forestry Research, 20, 31-36. doi:10.1007/s11676-009-0006-2

Turnbull, J. W., \& Pryor L. D. (1978). Choice of species and seed source. In W. E. Hillis \& A. G. Brown (Eds.), Eucalyptus for wood production (pp. 6-65). Adelaide: CSIRO. 